ENTREVISTA

\title{
REVISITANDO O BRASIL E O CAMPO ENTRE OS KISÊDJÊ (SUYÁ)
}

Anthony Seeger

Anthony Seeger foi aluno de graduação da Universidade de Harvard, e de doutorado da Universidade de Chicago, onde foi orientado por Victor Turner e por Terence Turner. Oriundo de uma família de músicos respeitados, Tony, como é conhecido, interessou-se desde sempre por música e performances rituais, e chegou ao Brasil, especificamente aos Kisêdjê (Suyá), como um dos pesquisadores do Harvard Central Brazil Project, coordenado por Maybury-Lewis, e do qual o seu orientador, Terence Turner, fazia parte. Acompanhado de sua esposa Judith Seeger e, mais tarde, de suas filhas nascidas no Brasil, Elizabeth e Hiléia, Seeger viveu com os Kisêdjê por longos períodos de tempo, produzindo descrições etnográficas detalhadas e originais sobre esse povo que inovaram o estudo da música e do ritual nas sociedades ameríndias.

Diretamente influenciado pela obra de Claude Lévi-Strauss, especialmente pelas Mitológicas, Seeger foi um dos primeiros autores americanistas a chamar a atenção para a centralidade das concepções relacionadas ao corpo e às práticas a ele relacionadas, como a ornamentação e a alimentação, na constituição de grupos e pessoas nessas sociedades, criando assim uma agenda própria de estudos, que libertou os americanistas dos esquemas conceituais oriundos da África e do Pacífico, então dominantes na antropologia, e pouco adequados para a descrição das sociedades ameríndias. Em uma célebre afirmação, Seeger sustenta que no lugar de grupos corporados encontravam-se ali "grupos corporais", em cuja configuração as substâncias, os líquidos, os fluidos e a comida exerciam papel central. A influência dessa abordagem para os estudos americanistas foi enorme, especialmente por meio de um conhecido artigo sobre a construção da pessoa nas sociedades ameríndias (publicado no Boletim do Museu Nacional, em 1978), coautorado por ele, Roberto DaMatta e Eduardo Viveiros de Castro, respectivamente seu colega e orientando no PPGAS/Museu Nacional, onde Seeger foi professor de 1975 a 1982.

De volta aos Estados Unidos, Seeger passou a se dedicar à curadoria e à produção musical, como diretor do Archives of Traditional Music, da Universidade de Indiana, diretor e curador do selo Folkways do Smithsonian Institute e, atualmente, diretor do Ethnomusicology Archive, da Universidade da Califórnia, Los Angeles (UCLA). Nesse contexto, produziu mais de 250 discos de música nativa, assim como uma importante reflexão sobre a questão do direito autoral e do patrimônio imaterial.

Esta entrevista foi concedida em março de 2012, no Departamento de Antropologia da UCLA, a Rita de Cácia Oening da Silva, doutora em antropologia social pela Universidade Federal de Santa Catarina e pesquisadora do Núcleo de Arte, Cultura e Sociedade na América Latina e Caribe (Musa), da mesma universidade. 


\section{Abrindo a conversa com o leitor}

Anthony Seeger é muito conhecido no Brasil por ter estudado e escrito sobre os Suyá, grupo Jê do norte do Mato Grosso do Sul, que atualmente se autodenomina Kisêdjê. Seeger é recebido com respeito por suas ideias e sua importante participação na história da antropologia brasileira. Seus livros e diversos artigos são fundamentais na formação de um etnólogo. ${ }^{1}$ É um dos mais influentes antropólogos da atualidade, tendo afetado diversos campos de estudo, entre eles a etnologia, a antropologia da música, as áreas que abordam a perspectiva do corpo e da produção da pessoa. A antropologia brasileira deve a ele um estudo em profundidade sobre os Kisêdjê. ${ }^{2}$

Mas Anthony Seeger também é conhecido e lembrado pela amizade e gentileza partilhadas com os brasileiros com os quais conviveu. Construiu relações com diferentes gerações e é comum se ouvir falar dele em função de sua "fineza" no trato. Além disso, morou e trabalhou num país sob ditadura, sofrendo suas mazelas; foi pesquisador e professor no Programa de Pós-Graduação em Antropologia Social do Museu Nacional, no Rio de Janeiro, entre 1975 e 1982, formando pioneiros antropólogos no Brasil; atuou em prol da causa indígena com afinco, tendo sido eleito presidente da Comissão Pró-índio do Rio entre 1979 e 1980. Por tudo isso, Seeger dispensa maiores apresentações.

A influência de seu trabalho cruza continentes e, em seu caso, a máxima "santo de casa não faz milagres" não é verdadeira. Ele mudou também a antropologia de sua terra natal. Depois de um longo período no Brasil, Seeger voltou para os Estados Unidos e lecionou em diversas universidades, orientando e formando profissionais. Entre 1982 e 1988 foi professor no Departamento de Antropologia da Indiana University, onde posteriormente dirigiu os Archives of Traditional Music, transformando a visão acadêmica sobre arquivos.

Foi ainda diretor do Smithsonian Folkways Recordings, da Smithsonian Institution, de 1988 a 2000. Nesse período, como diretor executivo, Seeger produziu cerca de 250 publicaçóes no Smithsonian Folkways Label, obra de imensa importância não somente porque registra e publica manifestações de culturas diversas, mas também porque permite que futuras gerações desfrutem da diversidade de sons e imagens produzida pela humanidade. Uma obra que certamente ficará na história.

O fato de ser um membro da família Seeger ${ }^{3}$ também lhe confere um lugar único na história dos Estados Unidos. Como ele mesmo assumiu numa conferência que proferiu na UCLA em 2012, "Are you related to...?" é uma pergunta que ouviu ao longo de sua vida. Não pôde fugir da história familiar, e a mesma pergunta fica como herança para as suas duas filhas, Elizabeth e Hiléia, que nasceram no Brasil e aqui passaram parte de sua infância. Embora tenha nascido numa família de pessoas famosas, em grande parte pessoas públicas, artistas, Anthony Seeger soube traçar sua própria trajetória intelectual, e deve a esse esforço e carisma a sua popularidade. No tempo que passei na $U C L A,{ }^{4}$ pude presenciar o imenso respeito que pesquisadores, alunos e fãs têm por ele como artista e pensador.

As conferências que proferiu na UCLA na "Série de Colóquios Nazir Ali Jairazbhoy", organizados pelo Departamento de Etnomusicologia da UCLA, ${ }^{5}$ período em que estive em contato com ele naquela Universidade, estavam sempre lotadas, com pessoas muito interessadas por suas histórias, ideias e pesquisas. As histórias que narrava eram sempre ricas em detalhes e contadas de modo gracioso, como um 
verdadeiro contador de causos sabe fazer, e vinham, aqui e ali, carregadas da emoção de quem viveu o que narrou. O jeito performático de iniciar suas falas, tocando banjo e cantando, atraía a atenção, ao mesmo tempo em que criava um clima especial e descontraído para o evento.

No dia 22 de março de 2012, numa das últimas semanas de Tony na UCLA, ele me recebeu na sua sala no Departamento de Etnomusicologia, e lá filmamos uma longa conversa que apresento parcialmente aqui. Para facilitar a leitura e a publicação da entrevista, ela foi dividida em duas partes. Numa delas Seeger fala sobre a presença da família no decorrer de sua pesquisa e das relaçóes com os Suyá. Esta parte será publicada em conjunto com uma entrevista feita com Judith Seeger e as duas filhas, Elizabeth e Hiléia, sobre suas próprias experiências no trabalho de campo acompanhando o pesquisador.

A segunda parte, esta que aqui apresento, aborda especialmente a relação de Seeger com os Kisedjê, a dos Kisedjê com a música e com a produção audiovisual, o modo como o pesquisador auxiliou o grupo a tomar posse das próprias imagens e das máquinas que as produzem, e a ética na pesquisa de campo.

Rita de Cácia Oenning da Silva - Você escreveu três importantes livros sobre grupos indígenas no Brasil: em 1980, Os índios e nós: estudos sobre sociedades tribais brasileiras; em 1981, Nature and society in Central Brazil: the Suyá indians of Mato Grosso, sua tese de doutorado; e em 1987, com segunda publicação em 2004, Why Suyá sing?: a musical anthropology of an Amazonian people. No prefácio da edição revisada de Why Suyá sing?, você diz que em Nature and society discute mais aspectos da estrutura e das mudanças da sociedade Suyá, e em Why Suyá sing? aponta mais as performances e os rituais, enfatizando o processo. Você poderia falar um pouco destas duas formas de abordar o campo (ou de escrever antropologia) e sobre os antropólogos que o influenciaram nestas duas obras?

Anthony Seeger - Quando eu estava no campo, fui estudar os Kisêdjê como parte de um projeto de pesquisa do Brasil Central - o "Harvard Brasil Central Project", que David Maybury-Lewis iniciou e do qual meu orientador, Terence Turner, participou estudando os Kayapó. Havia os alunos de David que estavam estudando os outros grupos indígenas: Melatti estudou os Krahó, DaMatta os Apinawé, Cris Croker os Bororo. Havia outras pessoas... e eu, como os outros, estava querendo contribuir para uma literatura que já existia sobre a sociedade Jê. Eu desejava colocar os Kisêdjê na literatura de maneira coerente, como os outros, o que quer dizer que eu estava olhando para a sociedade, o casamento, o parentesco e tudo mais, pois estas eram as coisas que chamavam a atenção nos Jê. De fato, havia mudanças especialmente nas terminologias de parentesco de um grupo para o outro, embora em certos aspectos da estrutura social não houvesse variação. Então, o primeiro livro é muito voltado para este tipo de apresentação.

Eu estava influenciado pelo trabalho de Claude Lévi-Strauss, que iniciou uma nova pesquisa sobre os Jê, tendo escrito um trabalho em 1952. Além de escrever sobre a organização social dos grupos Jê, ele produziu essa série maravilhosa de livros sobre mitologia - que era uma análise estrutural. Estava procurando a relação entre ideias e não somente a definição das ideias, utilizando os mitos e as etnografias dos grupos da América do Sul e da América do Norte. Quando eu estava entre os Suyá percebi que as categorias que surgiram nos livros Mito- 
lógicas (que não podiam na época incluir nada sobre os Suyá porque nada ainda havia sido colhido ou estudado) eram bastante úteis, bastante importantes: os cheiros, os sentidos, como ele escreveu em "Fuga dos sentidos". ${ }^{6}$ O mel tinha um papel bem curioso e importante na maneira de agir e de pensar dos Suyá/ Kisêdjê. Então eu pensava que de fato havia muitas coisas traduzíveis para os Kisêdjê, e de maneira bem interessante e importante.

Assim, meu livro [Nature and society] nasceu de uma familiaridade com o trabalho de Lévi-Strauss, e também com o de Kurt Nimuendajú, de Maybury-Lewis, e de todos os que estavam tentando entender essas estruturas sociais bastante fluidas e complexas. Mas, além disso, havia uma tentativa de confrontar as ideias sobre a sociedade de Karl Marx e Weber. Qual parte da sociedade influenciaria outras partes dessa mesma sociedade? Perguntava-me se a economia e os modos de produção eram predominantes e deveriam influenciar o ritual e todo o resto, ou se seria mais aplicável Weber quando dizia que as ideias criam uma infraestrutura econômica. Esta era a questão que eu achava mais importante na época, e ainda acho como debate nas Ciências Sociais hoje. Numa sociedade, qual é o papel das ideias e o papel da infraestrutura? Este tema foi bastante avançado por Marshall Sahlins. Na época eu estava lidando com as mesmas coisas que Sahlins, mas no campo. Então, esta era a questão de por que escrever o livro Nature and society in Central Brazil.

Eu estava argumentando, no sentido weberiano, sobre a ideia de dualismo de relações para entender outros aspectos da sociedade, desde noções de tempo e espaço até a prática de plantar, caçar e pescar. Eu não escrevi sobre música no primeiro livro. Deixei também de fora na tese de doutorado porque achava muito complicado. A tese já era muito grande e eu achava que ainda não entendia a música. Precisava voltar para o campo para entendê-la melhor. Depois da tese, que virou o livro Nature and society, voltei para o campo e melhorei este livro, mas também comecei a entender melhor a música suyá. Comecei então a compreender como [a música] estava estruturada, como era organizada e usada. O segundo livro não contradiz o primeiro. Sempre mostra como essas ideias, que parecem congeladas, estavam de fato sendo usadas e reelaboradas em processos de performance. Acho que estes dois livros não são tão diferentes; são dois aspectos da mesma coisa.

O trabalho do Giddens sobre estruturação me parece relevante neste caso, porque mostra que estrutura abstrata não existe; a estrutura está sempre sendo criada. Por outro lado, existem coisas que aparecem durante tempos e outras que são um contraponto a estas outras que são mais permanentes, mais consistentes.

\section{Poderia falar da ideia de processo e ritual e da sua relação com Victor Turner?}

Sim, certamente. Victor Turner foi um dos meus orientadores. O outro foi Terence Turner. Estes dois professores influenciaram muito meu trabalho. Eu fui para Cornell University a fim de estudar com eles na pós-graduação. Eles partiram no ano seguinte para Chicago e me levaram junto [risos], o que foi um grande alívio. Em Chicago encontrei muitas pessoas boas, mas os dois seguiram sendo as minhas principais inspirações. Victor Turner focava bastante no ritual, em transformação individual das pessoas, ideias e experiências individuais no processo de performance. Além das teorias e da experiência, ainda tinha a ideia de communitas, que se relacionava com as coisas sentidas e não somente com as 
coisas imaginadas. Estávamos nos anos 60 e communitas, para ele, deveria existir entre professores, alunos, todo mundo. Então, não era uma coisa abstrata. Era uma coisa vivida. Ele achava que devia ser vivenciado. Tudo isso influenciou o meu trabalho. Mas também eu venho de uma família que toca música há muitas décadas e eu sei o que é performance. Já sabia da importância da performance e da maneira como se criam emoções e estados de ser através da experiência em participar de concertos, passeatas, coisas assim.

Você poderia falar um pouco sobre a ideia de transformação como linha analítica para pensar os povos, seus contatos e suas mudanças?

Eu acho que a antropologia e a etnomusicologia têm errado em identificar grupos como separados, individuais ou autóctones, porque, de fato, quase todos os grupos estão em uma rede de relações com outros grupos - ou de casamento ou de troca, de guerra, de aprendizagem que é de longa duração. Então, eu também errei ao dizer que os Kisêdjê estão separados dos outros. Eles criaram trocas e são diferentes - eles se acham diferentes dos outros. Por outro lado, há muitos aspectos quanto ao que eles fazem, ao que eles plantam, como eles vivem, que vêm originariamente de outros grupos. Aculturação é uma coisa que acontece com os Jê. Em geral, há uma visão da história segundo a qual eles começam com poucas coisas e vão conseguindo outras; o que é hoje valorizado veio de outros grupos, de outros seres... podem ser até mesmo espíritos. A vida e a história para eles são aproveitamentos de oportunidades, geralmente praticados por um grupo de homens que sai da aldeia e traz para lá fogo, milho, cativos que ensinam novos rituais e, mais recentemente, geradores, parabólicas, gravadores e tudo o que obtêm para o bem do grupo. Há uma longa história dessa dinâmica; eu os ouvia falar que pegavam um tipo de mandioca de outro grupo e, quando viajavam, levavam consigo mudas.

\section{Presentes...}

Presentes, coisas. Havia então uma troca bastante forte de conhecimentos, de bens e de maneiras de viver. Certas coisas geralmente não são trocadas. Eles dizem que são os únicos que cantam akias, enquanto os outros cantam canções que os Kisêdjê aprenderam. Dizem que eles são os únicos que se lembram de certos cantos do Alto Xingu, pois os alto-xinguanos esqueceram os cantos do passado, sendo os Kisêdjê os detentores da tradição verdadeira. Evidentemente, no Alto Xingu, eles pensam a história de forma um pouco diferente. Acham que são eles os detentores desta tradição e que os Kisêdjê, ao se apropriarem dela, mudaram as coisas.

A próxima questão aborda as akias. Nos rituais que envolvem canto, você descreve especialmente dois gêneros musicais: 1. akia - em que os jovens homens (somente eles) devem compor suas músicas e cantar em conjunto; 2. ngere - estilo cantado por homens e mulheres. No verbete que você escreveu para Povos indígenas no Brasil, publicado pelo ISA (2003), você diz que as akias são um meio de os homens kisêdjê dizerem publicamente algo sobre sua individualidade. São canções compostas e cantadas por cada indivíduo, em registro agudo, com linhas melódicas e estilo característico. Pensando no modo como eles cantam as akias (em conjunto, mas cada qual com sua letra), me pareceu ser uma espécie de disputa, como acontece com os garotos que cantam rap, ou fazem breakdance, buscando destacar-se na sua performance. Os garotos do Recife 
chamam isso de "superar o outro" na sua performance. Existe uma espécie de embate quando se canta uma akia? Em caso afirmativo, qual é ele e como funciona?

A akia e o ngere são dois gêneros de música que geralmente aparecem juntos em qualquer ritual, um ao lado do outro. Sim, eles cantam o que é ou o que acham que pode ser, mas estão cantando para a comunidade, especialmente para suas irmãs. Os Kisêdjê estão se manifestando para todo mundo ver e ouvir. Os jovens cantam em tom agudo e também em alto volume para serem ouvidos e poderem assim se apresentar. Eles devem se destacar uns dos outros porque as outras pessoas estão ouvindo. A audiência é principalmente de mulheres, mas também de jovens, das namoradas dos jovens, então tem muita gente escutando, e é um tipo de aparição muito importante. É à noite. As mulheres ficam escutando na noite escura o grito, identificável pela voz e pelo canto. Elas também aprendem os cantos enquanto eles estão cantando. Estão escutando no entorno da aldeia. Parece cacofonia, mas não é. Os Kisêdjê (eles e elas) estão apontando para certa melodia. Para as mulheres não é o som total que é importante, mas as melodias individuais que estão sendo cantadas. Nunca ouvi falar do som como um todo, mas sim do som como melodias que podiam ser separadas. E para separar ouvindo, você tem que cantar bem alto.

E essas músicas são cantadas depois ou elas são esquecidas?

Geralmente, quando há outro ritual, aprendem novas canções. Por outro lado, as antigas são lembradas porque, depois da morte de uma pessoa, um parente passará o dia todo cantando cantos do morto para lembrar dele. Frequentemente, à noite, antes de cantar, essa pessoa consulta os outros velhos para saber como são e poder acertar as akias. De vez em quando, eles cantam todos os seus cantos também. A pessoa poderia passar o dia todo cantando os seus próprios cantos para alegrar todo mundo. Eu não tenho tantos, o meu dia seria muito curto. Eu só tenho algumas akias. Mas se você morar lá muitos anos, acumula. E você tenta lembrar de fato os cantos antigos enquanto está aprendendo os novos.

Como as crianças aprendem esses gêneros? Aprendem no convívio ou há algum momento em que se está compondo, e elas estão junto?

Ninguém compõe. Eles dizem que toda música vem de espíritos, de animais. Algumas pessoas têm a capacidade de ouvir e entender o canto de certas espécies da natureza. Vão andando pelo mato, ouvem canções; depois voltam e ensinam. Mas para cantar, sim, as crianças são ensinadas, começando muito jovens. Não sei se você viu o filme que eu fiz sobre Por que cantam os Suyá?, mas lá há uma cena em que as crianças, no momento em que ainda estão organizando o ritual, brincam vestidas para o rito, mas cantando. Assim vão aprendendo de fato a cantar akias, aquelas que serão cantadas nas semanas seguintes. Vão aprendendo, mas uma parte só. Não cantam as duas partes. Então, cantando sobre coisas ridículas, aprendem o estilo, aprendem o tipo de melodia em forma curta e depois aprendem as mais complexas e longas.

Como a tecnologia da sua época ajudou você em campo e como pensa que poderia ser com a tecnologia disponível atualmente?

Acho que hoje é difícil entender as dificuldades de equipamento que os pesquisadores tinham na década de 70 
e antes disso, porque o gravador de rolo era pesado, precisava de muita pilha, e as fitas eram curtas. Então, o maior problema para a gente era não gastar esse material antes do final do campo. Coisas importantes poderiam acontecer no último dia; era preciso ter material sobrando. Era uma angústia em função da pilha, mas também porque, se quebrasse o gravador, não teria como consertar na aldeia. Somente no Rio de Janeiro. Não havia outra opção, porque ninguém mais tinha gravador por perto. E ainda, era somente gravador de som. Gravador de imagem não existia na época. Eu tinha, como muitas pessoas na época, uma filmadora sem som, e era muito difícil sincronizar tudo, porque eu era um só. Precisaria de uma equipe: um manuseando a máquina de imagens e outro, a de som. Eu tenho muito pouca imagem em movimento, porque eram muito caros o filme, a revelação e a cópia. Mas acho que teria prestado mais atenção à dança se tivesse como gravar a dança e a música juntas, ao invés de separadas.

Esses aspectos certamente afetavam o modo como as pessoas investigavam, porque os que tinham geradores ou coisa parecida podiam tocar para a comunidade o que tinham acabado de gravar, e conversar sobre isso. Eu nunca tinha tantas pilhas para que pudesse tocar para eles o que eu tinha gravado. Era em parte por causa do peso, pois no avião da $\mathrm{FAB}$, mesmo que tivéssemos vontade, não podíamos levar muita pilha. Então, certas maneiras de fazer pesquisa, de gravar e de se analisar naquela época eram determinadas pela tecnologia. Hoje, eu não sinto o mesmo problema. Desde 94 estou levando placa solar com bateria de 12 volts para a região. Assim é muito fácil manter as pilhas recarregadas, o que não existia nas décadas de 60, 70. Na época, a análise de música por etnomusicó- logos era de peças pequenas - trechos pequenos de peças pequenas - o que, a meu ver, dificulta uma análise global da música.

Acho que não é por acaso que somente com o trabalho do Rafael sobre a jaguatirica e o trabalho de Maria Ignez de Mello e de Acácio Piedade é que estamos percebendo que existem suítes, que há estruturas muito maiores que duram dias, semanas. Em parte porque temos a tecnologia, que é capaz de mostrar isto. O Rafael Menezes Bastos procurava gravar tudo, tudo, tudo, e com bastante pilha e com gravador que funcionava de vez em quando - não funcionava tão bem, mas em geral funcionava... Eu não achava isto necessário e também não tinha capacidade de fazer a gravação de uma cerimônia toda. Agora estamos descobrindo coisas sobre músicas indígenas que nem imaginávamos.

Como um experiente pesquisador e um dos mais importantes antropólogos/etnomusicólogos da atualidade, você poderia apontar quais as premissas teóricas e éticas que considera importantes que um pesquisador etnomusicólogo/etnólogo tenha em mente quando vai para o campo pesquisar sociedade e música?

O campo mudou. A comunicação é muito mais fácil, as distâncias são mais fáceis de serem vencidas. Mas certamente eu acho que humildade é fundamental. É importante lembrar que são eles que sabem, e que nós não sabemos de nada. A tendência é ir buscar uma coisa tão específica que parece que já está tudo certo, mas de fato nada sabemos e só aprenderemos através de uma inocência completa. Por isso deixei os Kisêdjê me criarem como criança. Primeiro, porque eu não tinha muita escolha, mas também porque era a melhor maneira de aprender. 
Eu acho que agora, em termos de música e gravação, você tem que levar em conta o uso apropriado do material gravado. As permissões têm que ser muito claramente explicitadas e firmadas com as pessoas apropriadas... porque a internet mudou muito as coisas. No meu livro Natureza e sociedade no Brasil Central, digo que todo campo é um tipo de violência para as pessoas que estão sendo pesquisadas. E nós precisamos perguntar por que as pessoas suportam o pesquisador, quem é essa pessoa para eles e por que eles o ajudam e lhe ensinam sobre suas vidas. A pessoa que irá fazer a pesquisa deve pensar sobre isso. Por que todos devem estar abertos para conversar com ele? O que os pesquisadores trazem de benefício para a comunidade ou para as pessoas com quem trabalham? Esse benefício pode ser de curto ou longo prazo.

Eu vejo que agora as comunidades indígenas querem um compromisso de longo prazo para assuntos de posse de terra, educação bilíngue, escrita de projetos - coisas que pessoas que passam toda a sua vida aprendendo a ler e a escrever fazem bem. Para uma pessoa que tem contato com todos os níveis da sociedade é muito mais fácil do que para aquelas que não têm. Eu acho que o pesquisador de campo deve entender que vai para a comunidade para trabalhar a favor dela não somente enquanto faz a pesquisa, mas por um bom tempo depois. Eles não são obrigados a trabalhar com a gente. Eles têm toda a razão em perguntar: por que vamos trabalhar com esse pesquisador? E cada vez mais eles fazem esta pergunta.

Eu também escrevi outro texto sobre o pesquisador em campo. Foi publicado no Jornal de Etnomusicologia de Porto Alegre (Seeger 2008). Falo sobre pesquisa de campo de longo prazo e da minha perspectiva depois de fazer campo por
40 anos. Vale a pena ler o texto, porque a perspectiva é diferente daquela dos outros dois livros, que era a de um jovem fazendo pesquisa de campo pela primeira vez. Primeiro, apresentei este texto na reunião da $A B E T$ e, depois, Elizabeth Lucas me pediu para publicar. Sendo uma pessoa já de mais idade, estive tentando enfrentar a questão de quais são os benefícios e os malefícios de um campo que dura tantos anos. Há alguns benefícios para o grupo e para mim, mas também há desvantagens que têm que ser observadas.

No prefácio da segunda edição do livro Why Suyá sing? você faz uma distinção entre antropologia da música e antropologia musical. Você poderia falar um pouco sobre estas duas perspectivas teórico-metodológicas para pensar sociedades e a música e por que você escolheu a segunda?

No prefácio da segunda edição, eu estava contrastando o que eu queria dizer no meu livro com o trabalho de Allan Merrian, Antropologia da música. O livro de Merrian tenta mostrar como o estudo da música se beneficiaria com a aplicação direta da antropologia, com os assuntos da antropologia. Seu livro é importante e brilhante quanto à história do campo. Mas há coisas na música e na performance que poderiam influenciar também a antropologia. Não é somente uma via de mão única - deveria ser uma via de mão dupla. Uma antropologia musical voltaria sua atenção para a performance, para os processos, ao invés de os produtos. Eu acho ainda que a etnomusicologia deveria se pensar não somente como um importador de outros campos de ideias, mas também como exportador de perspectivas sobre processos sociais que poderiam beneficiar outros campos, seja a psicologia, a sociologia, a ciência 
política, e tudo mais. Em todas as áreas a música aparece e, observando como afeta processos, poderia melhorar esses outros campos também.

Este é o ponto central que eu queria salientar com o contraste entre o meu trabalho e o de Merrian, muito embora admire o que ele estava fazendo na época: o uso da antropologia para falar sobre a música. Eu queria que o livro também falasse para os antropólogos. Mas parece que foi pouco lido por eles. A etnomusicologia cresceu e todos os etnomusicólogos estão lendo, mas o número de cursos de antropologia em que este livro é usado é muito pequeno nos Estados Unidos. No Brasil, etnomusicologia se ensina como parte da antropologia, mas nos Estados Unidos isto acontece muito menos agora. No início havia três antropólogos e um etnomusicólogo na formação da sociedade de etnomusicologia (SEM - Society of Etnomusicology). Agora acho que um décimo dos membros é de formação antropológica. Geralmente são os mais velhos que são antropólogos, porque depois foi nas escolas de música que se empregaram etnomusicólogos e que se criaram programas de pós-graduação em etnomusicologia; era ali que se tratava de etnomusicologia.

Queria falar sobre um texto famoso seu: aquele que você, DaMatta e Viveiros de Castro escreveram: "A construção de pessoa nas sociedades indígenas brasileiras", que foi muito significativo para a etnologia brasileira - para não dizer sul-americana. De fato, tem sido um importante motor dos estudos indígenas no Brasil. Talvez um dos seus textos mais citados.

[Rindo] Certamente o meu texto mais citado, especialmente no Brasil.

É um texto fantástico, com um tom de manifesto, que visivelmente se opõe aos estudos e às abordagens feitas sobre os povos da América até aquela época (1978). Você poderia falar um pouco sobre essa proposta e sobre os impactos ou as mudanças alcançados na abordagem mundial sobre esses povos da América do Sul? Como você percebe que mudou $a$ antropologia brasileira desde então?

Acho que o impacto deste texto foi forte posteriormente, mas na época não eram tão exclusivas essas ideias que nós estávamos apresentando. Estávamos querendo nos opor à importação sem muita reflexão a respeito de certos conceitos e ideias sobre sociedade de base (como linhagem), sem adequá-los à ideologia e ao funcionamento das sociedades indígenas no Brasil. Conceitos estes que mal serviam aqui, certas ideias de organização social provavelmente mais aplicáveis na Nova Guiné e na África do que no Brasil. Mas estávamos criando essa posição também em cima de conceitos como o de pessoa de Dumont, conceitos de Lévi-Strauss e de vários outros pesquisadores sobre questões importantes das sociedades indígenas brasileiras. Da ideia de pessoa, da criação da pessoa... Era patente que os nomes eram mais importantes que patrilinhagem, por exemplo, como meio de criar identidade.

Aproveitávamos ideias que já estavam circulando na antropologia, e queríamos fazer um tipo de manifesto dizendo: "Bom, para a sociedade indígena no Brasil, temos que escutar o que eles estão dizendo e analisá-los nos seus próprios termos" - que não eram necessariamente os termos apropriados e usados na África e na Nova Guiné. Foi bastante divertido escrever, para mim especialmente, porque um era meu orientador - o Roberto DaMatta - e o outro era meu orientando o Eduardo Viveiros de Castro. Então, éramos três gerações com ideias um pouco diferentes tentando escrever a seis mãos 
um trabalho curto. Foi divertido e eu acho que saiu forte por isso, porque Eduardo era brilhante e Roberto sabia muita coisa sobre literatura de antropologia social e também tinha sua experiência com os Jê. Eu estava no meio deles. Juntos tentamos criar um documento que fizesse algum sentido.

Fizemos um Simpósio sobre o conceito de pessoa nas sociedades da América do Sul, e convidamos Melatti e outros, e todos fizeram trabalhos interessantes; todos estavam reagindo do mesmo modo. Havia uma coerência no congresso por causa desse texto. Depois, mandamos para os outros participantes do Simpósio um rascunho do texto, que foi publicado muito rapidamente pelo Museu Nacional e teve ampla divulgação. Isso foi há muitos anos e eu não me lembro de quem escreveu qual parte; nós brigamos pouco, mas o tempo era muito curto para escrever a seis mãos, porque, você sabe, não tinha computador na época. Não era possível mandar por correio eletrônico, Word, ou coisa parecida. Era tudo no papel. Datilografia e circulação manual. E muita conversa, que era a parte mais agradável.

Como mudaram as coisas? As ideias estavam no ar e o texto deu um certo foco. Certamente foi uma publicação para a qual se podia apontar para justificar uma pesquisa sobre as ideias indígenas na América do Sul, sobre a sociedade. Então, eu não sei se foi tão revolucionário. Devemos também apontar para o movimento que existia na época, com os outros do Simpósio e também com nossos alunos. Assim, parece ter sido uma guinada, porque todo mundo cita isso, mas as ideias não eram unicamente nossas.

Era um manifesto mais geral que estava acontecendo na academia brasileira...

Não em todas, porque havia academias brasileiras que estavam muito apegadas às outras ideias sobre sociedade, mas nós estávamos fazendo isso.

Os Suyá/Kisêdjê estão envolvidos com a produção de Vídeo nas Aldeias. Os realizadores indígenas kisêdjề gravaram um filme justamente sobre o Ritual do Rato, que você analisa no seu livro Why Suyá sing? Você foi um dos pioneiros no incentivo dos Kisêdjê/Suyá para a produção audiovisual, não foi? Como foi isso?

Acho que foi em 1993 que eu recebi um fax na Smithsonian Folkways me chamando para dar uma consulta aos Kisêdjê. Eles mandaram um fax dizendo: "Estamos com muitos problemas de terra e, antes de fazermos uma coisa drástica, queremos falar contigo". E eu imediatamente me propus a ir, mas estava com família e emprego; precisava me planejar para ir no verão, nas férias de 94. Fiquei pensando de que modo eu poderia ajudar, caso se tratasse de problema de invasão. Eu não sabia que eles iriam invadir fazendas para retomá-las. Tentava imaginar o que seria uma ajuda nessa história, já que era muito provável acontecer violência. Os Kisêdjê poderiam ser mortos por pessoas bem mais armadas e determinadas.

$\mathrm{Eu}$ achei que seria interessante ensinar-lhes a usar o vídeo para que pudessem filmar os invasores, entregar para a Polícia Federal e deixar a polícia, mais bem armada, tirar e identificar as pessoas que estavam invadindo. Então, pensei que seria interessante comprar equipamento para fazer vídeo, treinar pessoas para usar esse equipamento e também comprar um barco a motor para que eles pudessem usar para vigiar seu território. Pedi dinheiro para o Grateful Dead ${ }^{8}$ porque eu estava trabalhando com o Mickey Hart na época. Ele era o baterista do Grateful Dead, e eles tinham uma Fundação. Eu pedi dinheiro 
para comprar o barco, o equipamento de vídeo, para o treinamento etc. Eu já conhecia o início do trabalho do Vídeo nas Aldeias, já sabia que Terence Turner estava filmando com os Kayapó, mas meu objetivo era bem concreto. Estava tentando resolver problemas de invasão sem violência direta entre grupos, ou seja, entre os Kisêdjê e as pessoas ao redor.

Bom, a coisa mudou muito. Depois que o dinheiro chegou ao campo, eles já tinham tomado três fazendas e estavam se defendendo de acusações de invasão. Então, eu segui um ritmo: cheguei e entreguei todo o equipamento. Eles achavam muito mais interessante virar as máquinas para si mesmos e não para o exterior, porque eles tinham resolvido grande parte do problema dos invasores. No momento de fazer o orçamento, eu perguntei a Vincent Carelli, a quem eu já conhecia há muitos anos: "Vincent, posso mandá-los para serem treinados por você lá em São Paulo?". E ele disse: "Sim, claro, pode". Mas o chefe suyá/ kisêdjê estava muito preocupado em mandar dois jovens para São Paulo. Ele achava que seria perigoso e que era longe demais. Então, ele disse: "Eu quero mandá-los para Brasília. Você pode encontrar alguém em Brasília?". Encontrei uma pessoa em Brasília, mas que não tinha o mesmo tipo de formação e experiência que o Vincent tem; mas pelo menos lá também aprenderam como filmar, como editar e fizeram um projeto que foi apresentado numa Mostra de Filmes em Brasília. Foi tudo ótimo. Eu fiquei muito contente. Eles voltaram para a aldeia, e um deles é um excelente cinematógrafo. O outro usa menos a câmera. Mas eles levaram muito a sério essa coisa de se documentar. Mas eu digo novamente que a novidade que eu estava querendo promover era fazer chegar a filmadora na aldeia antes das parabólicas e da televisão. Queria que eles ganhassem conhecimento das ferramentas de produção antes das do consumo. Seria uma grande oportunidade para isso.

Eles então teriam uma visão do que chega de fora muito diferenciada, não é?

Sim, muito diferenciada. Eu tinha visto a mesma coisa na década de 70. Havia na aldeia três rádios de onda curta. Por esses rádios só se podia escutar o que outros mandavam. Não se tinha nenhum controle, exceto desligar. Felizmente eles não tinham muita pilha; em geral, acordavam cedo e cantavam, mas nos dias em que eles não queriam cantar, ligavam o rádio. Às 5 horas da manhã. De repente, aparecia uma reportagem sobre o trânsito em Goiânia [risos e voz alta]: "Alô, alô Brasil central, estamos a 06 horas e 45 minutos da manhã, e o trânsito está pesado no Avenida Getúlio Vargas...". Coisa absurda no meio do mato [risos altos]. Depois de poucos anos, entrou o gravador. Barato, fácil de manusear e não precisava de pilha grande, pesada - utilizava pilha menor. Os Suyá começaram rapidamente a usá-lo, e não utilizavam coisas pré-gravadas. Eles gravavam suas vozes ou trocavam fitas com outros grupos indígenas.

Quando em 80 eu fiz um levantamento das fitas de um kisêdjê, ele tinha fitas deles, do Alto Xingu, fitas de discurso sobre a política indigenista de Brasília, fitas da família Seeger que eu tinha mandado. Eles não tinham muita coisa de fora. Quando gravaram suas próprias festas, gravaram de modo muito interessante, porque conheciam a estrutura da sua música. Então, eles pegavam somente as partes principais. Eu, não sabendo quais eram as principais, gravava tudo, gastava as pilhas, e eles riam. Então, eles começaram a me dar fitas gravadas em troca de fitas virgens. Assim, eu ganhei uma imensa quantidade de material, de 
momentos em que eu não estava presente para ver a gravação, e que estava gravado de maneira bem diferente do que eu fazia. Isso era uma coisa bastante instrutiva. Mas eu diria que a diferença entre rádio de onda curta e gravador cassete é o mesmo tipo de diferença entre receber emissão de televisão e fazer sua própria televisão. É outra coisa.

\section{Outra abertura, outro domínio.}

Outra abertura, outro pensamento, outros valores, e outras possibilidades também. E para representar a música, o vídeo é muito melhor que o áudio, porque quase toda música é dançada, e quase toda música é apresentada com o corpo pintado, com ornamentos, pena e tudo mais.

[A filmadora apresenta defeito e eu tento consertar. Seeger comenta: "Mas o áudio está funcionando bem e é muito mais importante me gravar do que me filmar, porque eu estou aqui sentado nessa sala sem me pintar, sem penas, sem ornamentos (risos). Vamos acabar somente com o áudio". Respondo: "Acho que vai dar com o vídeo".]

Só para dizer que agora eles têm uma pequena oficina de produção e estão solicitando verbas para comprar máquinas e se documentar melhor. E estão conseguindo verbas de várias fontes, inclusive do Iphan, porque há uma corrida de toras que eles não fazem desde 1940 e tanto, eu acho. Antes, bem antes de eu chegar lá. Eu nunca vi; sempre ouvi falar. Então, eles estão querendo fazer enquanto ainda existem pessoas com memória em função de terem visto. Espero que aconteça.

\section{E eles querem filmar...}

Eles querem filmar, documentar. Eles têm um lindo vídeo sobre a festa do Rato, sobre a qual eu escrevi um livro, e incluíram ali um pouco da filmagem que eu fiz com a antiga máquina sem som. Eu também fiz um vídeo baseado em coisas que gravei em 96 . Eu já havia escrito o livro e queria mostrar o que eu havia descrito. Mas o deles é muito mais engraçado e muito mais agradável de ver porque, entre outras coisas, eles conheciam bem o ritual, e o equipamento que eles têm é mil vezes melhor que o equipamento VHS que eu tinha em 96. Mas a maneira como eles filmam também é muito melhor que a minha. Eles são muito melhores.

Talvez pelo fato de que eles sejam do grupo, o que permite serem jocosos, brincar... porque a gente, como pesquisador, tem um certo cuidado em respeitar os espaços; já para eles fica mais claro onde pode e onde não pode entrar.

Quando eu filmava, me posicionava não no meio das pessoas cantando, mas um pouco fora, porque eu fico sem jeito de entrar no meio das atividades que eles estão fazendo. Mas eles obviamente não. Eles me convidaram para entrar no evento, e eu não fui porque achava que era um tipo de invasão não justificável. Mas eles se divertem bastante fazendo filmes.

Você se tornou um grande defensor dos arquivos. Este tem sido um importante trabalho seu na UCLA e no Smithsonian. Sua posição teórica sobre o tema traz uma perspectiva interessante sobre a importância dos arquivos na vida das pessoas. Você já falou sobre isso em vários textos, mas trata-se de um tema significativo. Você poderia falar um pouco mais sobre isso?

Existe a ideia de arquivo como um lugar cheio de mofo, e com pessoas desagradáveis, que não ajudam ninguém a fazer a pesquisa. Espaço em que as coisas vão 
para desaparecer. Eu acho totalmente injusto. Eu acho que arquivos também podem ser lugares de descoberta, de renascimento, e eles estão sendo usados assim. A tentativa dos grupos indígenas de documentar o presente para mostrar a seus netos no futuro será muito difícil sem a presença de arquivos, do uso cuidadoso de arquivos, porque de fato os formatos dos vídeos estão ficando rapidamente obsoletos. É muito difícil pegar um vídeo de 30, 25 anos atrás e reproduzi-lo hoje. E eu acho que vai piorar no futuro. Então, é necessário haver certas instituições que estejam voltadas para a preservação e a migração de material para que este possa ser usado no futuro pelas pessoas quando quiserem usar.

Durante muito tempo os Kisêdjê não se mostraram interessados pelo material que eu estava gravando. Eu sempre falei: "Bom, estou colocando no arquivo em Indiana. Se seus netos quiserem ir um dia para Indiana, podem ir...". Eles conheciam tudo isso, e não queriam uma cópia. Isto até 2003 mais ou menos, quando eles me pediram uma cópia de tudo o que eu tinha gravado para colocar no seu próprio Centro Cultural, o que eu achei ótimo. Era o momento que eu estava esperando, porque não queria dar sem um pedido, porque era para fazer o quê? Não tinha onde tocar, não tinha nada. Eu mandei tudo. Consegui uma cópia digital de todo o material gravado em rolo (o primeiro, o mais antigo) e das gravações feitas em cassete em uma época posterior, e mandei para lá. Eles estão usando entusiasticamente, colocando os seus vídeos, usando não somente para consagrar o passado, mas para criar coisas novas no presente para o futuro.

Acho que isso é uma coisa que ainda vai acontecer muito, mas só se tiver um lugar para guardar. Os vídeos que eles fizeram em 96, 97, eu trouxe para cá, fiz cópias e mandei para eles, mas já estavam bem estragados antes de chegarem aqui. O vídeo é muito difícil de proteger em lugar úmido. Geralmente mofa e, depois de mofar bastante, fica muito difícil de melhorar. Então, espero que Vídeo nas Aldeias esteja tomando muito cuidado com seu material gravado, porque as fitas não são permanentes. É muito temporário.

Sim, degrada muito rápido. Falando sobre a etnomusicologia brasileira, ou melhor, sobre os estudos antropológicos que se preocupam com a música, na sua opinião, quais são os aspectos mais frutíferos dos trabalhos brasileiros que envolvem estudos de sociedade e música?

Na década de 70 éramos poucos etnomusicólogos no Brasil. Talvez três ou quatro no país todo. E agora podem ser quatro numa universidade só, ou numa cidade só. Então, eu fico muito impressionado com o campo do estudo de música no Brasil e com a etnologia da música, ou seja, com uma visão antropológica da música e não somente com uma visão, vamos dizer, estética. O crescimento é ótimo. Há muitos trabalhos fundamentais sendo feitos no Brasil. Eu acho que o grupo de Rafael Bastos, o MUSA, que estuda os grupos indígenas, é um dos melhores grupos no Brasil, melhor dizendo, no mundo. No MUSA há pessoas formidáveis, estudando música de maneira bastante séria e interessante. E o Rafael também. No Brasil, em termos de etnomusicologia, em geral, há muita diversidade.

Existem muitas maneiras de aproximar o campo e as pessoas que estão localizadas em muitas partes da universidade, o que eu acho bom. Uma coisa do campo mundial que tem chamado a atenção é o trabalho do Samuel Araújo e do seu grupo lá na Maré. Trabalham não somente com a universidade, mas também com a comunidade, para trans- 
formar o nosso conhecimento sobre a música deles e o da comunidade em si, especialmente de certas pessoas de lá.

Este é um tipo de antropologia aplicada bastante original, e que não vem sendo feita em muitos lugares. E é o Samuel e seu grupo, porque ele insiste em que todos sejam reconhecidos em reuniões internacionais, nos Estados Unidos e em outros lugares fora do Brasil, levando essa visão da possibilidade de uma etnomusicologia bastante renovadora e diferente pelo mundo afora, o que eu vejo como uma grande contribuição. Há outras contribuições também. Há muita gente boa. Nos últimos anos, o Brasil tem investido muito dinheiro para os professores viajarem, para participarem de reuniões internacionais, e acho que a presença dos pesquisadores brasileiros é cada vez maior no exterior, o que considero ótimo, porque sempre achei que os trabalhos de antropologia social são especialmente fortes no Brasil, e os de etnomusicologia também o são. A última pergunta é se eu pretendo ir para o Brasil?

\section{É. Sua participação na antropologia} brasileira foi muito frutífera. Você tem algum plano ou projeto de voltar a fazer pesquisa no Brasil?

Eu tenho ido bastante ao Brasil nos últimos anos, desde 90. Por 12 anos eu fui pouco ao Brasil e fui pouco à aldeia dos Kisêdjê. Quando eu saí em 82, pensei que estava me despedindo pela última vez, porque estava voltando para os Estados Unidos. Mas voltei para os Kisêdjê porque eles me chamaram. Eles mandaram esse fax, essa carta através de fax, de Brasília para o Smithsonian. E eu voltei depois disso para a aldeia a cada dois anos, mais ou menos, então, foi bastante visita. E para o Brasil em geral, igualmente. De vez em quando dou conferências em vários lugares. Enquanto estou no país, sou muito convidado para bancas de tese e de dissertações, nas quais sempre me divirto. Acho muito agradáveis. E, quem sabe, agora que estou me aposentando na UCLA, eu possa ser professor visitante vez por outra no Brasil, num período de um semestre, ou coisa assim.

\section{Esta é uma boa ideia.}

Vamos ver o que acontece. Mas eu tenho muitos bons amigos no Brasil, de muitos anos, e também muitos alunos que ocupam posições de alta responsabilidade. É bastante divertido quando eu vou ao Brasil, porque os alunos dos meus alunos olham para mim e dizem: "Você foi professor do meu professor". Daí querem autógrafo e muitas fotos, coisas assim [risos]. Dá uma grande satisfação, porque éramos poucos no passado, e eu fui parte na formação de quase todos.

Quando você disse na sala de aula que você tinha escrito umas coisinhas no Brasil, eu tive que dizer que não eram somente "umas coisinhas"...

Claro, foi mais que isso, mas eu sou muito mais lembrado por esse trabalho que eu escrevi com DaMatta e Viveiros de Castro, que foi divertido de escrever e marcou o momento. De fato, as coisas já estavam mudando naquela direção, mas quando você publica algo, de repente atrai o raio. Fica como ponto de referência para as outras pessoas justificarem o que estão fazendo e que iriam fazer de qualquer jeito. Por isso, acho muito importante publicar o que se escreve, porque você pode pensar sobre qualquer assunto, mas não vai ser usado e não influenciará da mesma maneira se não for publicado. Falar sobre isto com duas pessoas, três pessoas, é importan- 
te, mas não vai impactar tanto. Quando cheguei aqui nos Estados Unidos, quase ninguém estava escrevendo sobre o trabalho em fonotecas e arquivos. Como eu escrevo sobre tudo, escrevi sobre isto e, de repente, eu era o expert, a pessoa mais conhecida por meu trabalho sobre arquivo, simplesmente porque escrevi.

\section{Muito obrigada, Tony. Tomei bastante o seu tempo.}

Tem que tomar. Se quiser fazer perguntas, tem que ter tempo.

\section{Notas}

${ }^{1}$ Embora duas das principais obras do autor sobre este grupo, Nature and culture e Why Suyá sing?, não existam em português, são leituras obrigatórias sobre a etnologia brasileira. Em Nature and culture, o autor escreve sobre como a sociedade Suyá está organizada, abordando temas clássicos como parentesco e organização política. Em Why Suyá sing?, Seeger empenha-se em mostrar a performance dos rituais do grupo. Uma terceira obra é extremamente difundida no Brasil, tendo tido um grande impacto no modo de pensar e fazer antropologia. Trata-se do artigo "A construção da pessoa nas sociedades indígenas brasileiras" (1979), publicado em parceria com Roberto DaMatta e Eduardo Viveiros de Castro.

${ }^{2}$ Nos últimos anos, além das publicações sobre antropologia musical, na qual discute a necessidade de a antropologia se deixar afetar pelas artes, Seeger tem trazido frequentemente ao Brasil a sua discussão sobre Arquivo - tema nem sempre pensado por muitos de nós, antropólogos, mas que vem sendo revitalizado a partir da importância de se ter a diversidade de sons e imagens que existem no mundo produzida e arquivada.
${ }^{3}$ É neto do conhecido estudioso de música Charles Seeger, um dos professores pioneiros do Departamento de Etnomusicologia da UCLA, onde o próprio Anthony iria lecionar posteriormente. Outro parente muito conhecido é Peter Seeger, um ícone da música folclórica norte-americana, conhecido por suas canções de protesto. Numa conferência que proferiu na UCLA, Anthony Seeger falou de seus muitos outros parentes que tiveram ou têm vida artística e pública.

${ }^{4}$ Entre janeiro e março de 2012.

${ }^{5}$ A "Série de Colóquios Nazir Ali Jairazbhoy" apresenta uma variedade de leituras que enfocam pesquisas e temas importantes no campo da etnomusicologia.

6 "A fuga dos cinco sentidos", na obra de Claude Lévi-Strauss, $O$ cru e o cozido.

${ }^{7}$ Kanbrinti Suyá, Kamikia P. T. Kisêdjê, Kokoyamaratxi Suyá, Whinti Suyá, Yaiku Suyá.

${ }^{8}$ Grateful Dead é uma banda estadunidense de rock, formada em 1965, em São Francisco, Califórnia, e é considerada a precursora do movimento Hippie.

\section{Referências bibliográficas}

BASTOS, Rafael José de Menezes. 1999. A musicológica kamayurá: para uma antropologia da comunicação no Alto Xingu. Florianópolis: Editora da UFSC.

BLACKING, John. 1967. Venda children's songs: a study in ethnomusicological analysis. Johanesburg: Witwatersrand University Press. . 2007. "Música, cultura e experiência". Cadernos de Campo, 16:01-304.

ISA - Instituto Socioambiental. 2003. Enciclopédia dos povos indígenas no Brasil. Disponível em: http://pib. socioambiental.org/pt/povo/kisedje. Acesso em: 01/03/2012. 
LÉVI-STRAUSS, Claude. 1989. "Mito e música". In: Mito e significado. Lisboa: Edições 70.

MERRIAN, Alan. 1980. The Anthropology of Music. Evanston, Illinois: Northwestern University Press.

NETTI, Bruno. 1983. The study of ethnomusicology: twenty-nine issues and concepts. Urbana: University of Illinois.

SEEGER, Anthony; DAMATTA, Roberto \& VIVEIROS DE CASTRO, Eduardo. 1979.

"A construção da pessoa nas sociedades indígenas brasileiras". Boletim do Museu Nacional, 32.

SEEGER, Anthony. 1980. Os índios e nós: estudos sobre sociedades tribais brasileiras. Rio de Janeiro: Editora Campus. . 1987. Why Suyá sing?: a musical anthropology of an Amazonian people. Cambridge: Cambridge University Press. With audio cassette and examples of speech and song.

. 2004. Why Suyá sing?: a musical anthropology of an Amazonian people. Illinois: University of Illinois Press. With a CD. . 2008. "Long-term field research in ethnomusicology in the 21st-Century". Em Pauta, 19(32-33):03-20.

SEEGER, Judith. 1990. Count claros. Study of a ballad tradition. New York \& London: Garland Publishing, Inc. 